\title{
COFFEE AND COUNSEL CLINIC: CONSTRUCTING A MORE COMFORTABLE PLACE FOR LEGAL AID IN THE SUB-URBAN COMMUNITY
}

\author{
Waspiah Waspiah ${ }^{1 *}$, Rodiyah Rodiyah ${ }^{2}$, Andry Setiawan ${ }^{3}$, Kartika \\ Fajar Cahyani ${ }^{4}$, Adinda Ratna Pertiwi ${ }^{5}$, Bayu Bimantara ${ }^{6}$ \\ ${ }^{1,3}$ Department of Private and Commercial Law, Faculty of Law, Universitas \\ Negeri Semarang, Indonesia \\ ${ }^{2}$ Department of Administrative and Constitutional Law, Faculty of Law, \\ Universitas Negeri Semarang, Indonesia \\ ${ }^{4}$ Faculty of Law, Universitas Negeri Semarang, Indonesia \\ ${ }^{5,6}$ Undergraduate Student, Faculty of Law, Universitas Negeri Semarang \\ *Email: waspiah@mail.unnes.ac.id
}

Legal assistance is one of the needs of the community in the midst of many legal cases today. The existing consultations and assistance also seem formal and very rigid, such as being carried out in offices and the like. In fact, in the success of legal assistance, the comfort of both parties is the main key. This program emphasizes the development of a more comfortable pattern of legal assistance and consultation by combining coffee shops as an alternative place for legal consultation. This program was developed and implemented in Wanureja Village, Tegal, Kendal Regency, Indonesia. This place and program have continually provided clients with access to the best legal advice and representation available,

The Indonesian Journal of International Clinical Legal Education DOI: https://doi.org/10.15294/ijicle.v3i3.48609

Submitted: Dec 12, 2020 Revised: May 23, 2021 Accepted: July 29, 2021 Available online at https://journal.unnes.ac.id/sju/index.php/iccle (C) 2021 Authors. This work is licensed under a Creative Commons AttributionShareAlike 4.0 International License (CC BY-SA 4.0). All writings published in this journal are personal views of the authors and do not represent the views of this journal and the author's affiliated institutions.

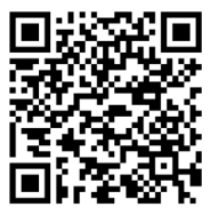


Waspiah Waspiah, et.al.

all in an informal, stress-free setting with a low cost for the initial consultation. We meet you where you are most comfortable -an inperson meeting at an attorney's office, a conversation at the local coffee house, or if you are disabled or incapacitated in any way, at your location.

Keywords: Legal Assistance; Paralegal; Legal Counseling; Coffee Shop

\section{INTRODUCTION}

The United Nations Principles and Guidance is the first international instrument to recognize the role of paralegals as providers of legal aid services. The 14th principle states that the state must "recognize and encourage the contribution of lawyers' associations, universities, civil society and other groups and institutions in providing legal aid". Guidelines 1, 5 and 13 develop further in encouraging countries to involve other actors in regulating legal aid including involving paralegals and law students.

The Legal Aid Law does not explain the meaning of paralegal, but in general, based on the experience of providing training to paralegals at the Legal Aid Institute (LBH), a paralegal is anyone who has been trained and has knowledge and skills in the field of law that helps resolve legal problems faced by legal aid workers. other people or their community. In carrying out his role, usually a paralegal is supervised by an advocate who works at LBH. Paralegals become a bridge that connects advocates and poor communities in areas that are difficult to reach by advocates. Paralegals who are educated by LBH usually come from communities that have legal problems who are trusted by members of the community in the community to represent their legal interests. Paralegals educated by $\mathrm{LBH}$ in paralegal training are people who are committed to helping prevent and resolve legal problems in their community. The training materials provided to paralegals contain basic legal materials and advocacy strategies so that later they can become community assistants to report cases that occur in their mentoring area and maintain coordination and supervision of handling cases to advocates at $\mathrm{LBH}$. People who have legal problems can also get an initial diagnosis of their legal problems from paralegals. Paralegals can ask for opinions from advocates and if needed can follow up their cases to advocates at LBH. Legal Aid Organizations should exercise their right to recruit paralegals by developing paralegal education and improving paralegal capabilities so that geographical factors and the limitations of lawyers do not justify the non-fulfillment of the right to legal aid for the poor and marginalized. 
Paralegals are often known as companions, who carry out legal activities as carried out by lawyers, namely providing legal assistance both through the courts and outside the court, to the extent of the capabilities possessed by people who carry out paralegal activities. Because of its nature to assist in handling cases or cases, paralegals are often also referred to as legal assistants, in everyday practice, the role of paralegals is very important to be a bridge for justice-seeking communities with advocates and other law enforcement officers to resolve legal problems experienced by individuals and groups. ${ }^{1}$

According to Black Law Dictionary in his book Mulyana W.K. states that Paralegals are A person with legal skills, but who is not an attorney, and who works under the supervision of a lawyer or no is otherwise authorized by law to use those legal skills. Paralegal courses leading to dresses in such specially are no afforded by many schools. Based on this understanding, what is called a paralegal is someone who has legal skills but is not a legal advisor (professional) and he works under the guidance of an advocate or who is judged to have the legal ability to use his skills.

In the same context, D.J. Ravindran also emphasized that paralegal is: Someone who has basic knowledge of law, both procedural law (formal), material law, and the motivation, attitude and skills to Implement educational programs so that disadvantaged people are aware of their rights, namely:

1) Facilitate the formation of people's organizations so that they can demand and fight for their rights;

2) Assist in mediation and reconciliation when there is a dispute; and

3) Conduct preliminary investigations into cases that occurred before being handled by lawyers;

The concept of paralegals in providing legal assistance is a concept to encourage the acceleration of achieving access to justice for the community, especially in suburban areas. Various methods of legal assistance and consultation were carried out, both formally (in the office) and informal (outside the office). Various types of legal aid services, legal assistance, and legal consultation have also developed, one of which is by combining cafes as a place of consultation. This method is

1 Herdiana, D., Susanto, S., Iqbal, M., Indriani, I., \& Supriyatna, W. (2021). Pelatihan Penggunaan Aplikasi E-Court Untuk Paralegal Di Lembaga Bantuan Hukum" UNGGUL". Abdi Laksana: Jurnal Pengabdian Kepada Masyarakat, 2(1), 110-115; Sihombing, E. N. (2019). Eksistensi Paralegal dalam Pemberian Bantuan Hukum bagi Masyarakat Miskin. Jurnal Ilmiah Penegakan Hukum, 6(1), 70-77; Noni, N. P. N. S., Sugiantari, A. A. P. W., \& Nistra, I. M. (2021). Efektivitas Peraturan Menteri Hukum dan HAM Nomor 1 Tahun 2018 Tentang Paralegal Dalam Pemberian Bantuan Hukum Di LBH-APIK Bali. Jurnal Analisis Hukum, 4(1), 16-33; Rahardian, R., Haryanti, R. H., \& Kurnia, N. A. S. (2018). Evaluating The Use of Paralegal Approach in Policy Advocacy. JKAP (Jurnal Kebijakan dan Administrasi Publik), 22(1), 14-19. 
Waspiah Waspiah, et.al.

considered as a form of legal consultation that is more convenient and increases rigidity in providing legal services for clients. ${ }^{2}$

Several coffee shop concepts with legal service providers and legal consultations continue to develop in various regions, be it Semarang, Bandung, or Jakarta. This concept provides an alternative for clients to get more comfortable and intensive legal and consulting services.

In Semarang, for example, this coffee shop (KOPI LAW) located on Jalan Seroja, Semarang City, does not only provide coffee, but also provides free legal consultations. The owner of the coffee shop, Hendra Wijaya, said that the purpose of making this law coffee shop was to provide free legal consultation and legal assistance, especially for the poor or the lower middle class. Many people have also taken advantage of the legal consultation at the shop, ranging from termination of employment, bad credit to fraud. One of the visitors even admitted that he represented some of the workers' friends to consult regarding bad loans experienced by workers during the Covid-19 pandemic. Many of his friends have become victims of layoffs, but the installments from banks or other financial institutions still have to be paid in installments. ${ }^{3}$

Besides Semarang, there is also a similar shop in Bandung. The coffee shop that has three alumni of the Faculty of Law, Pasundan University (Unpas) is quite unique. Named Pura Koffie, this coffee shop located on Jalan Pungkur, Bandung City can be a place for free legal consultations. Visitors who come can consult about the legal problems they face. In fact, visitors can ask anything about the legal world. The legal consultants are directly the owners of Koffie Temple, respectively Pranjani Harianto Lumbanraja, Ulfa Prasatya Putri, and Agita Yolanda Agustin. Their knowledge as graduates of the law faculty is the basis for finding solutions to visitors' problems. In handling cases, they will prioritize mediation. The hope is that existing legal problems can be resolved without having to take legal action. However, if the matter is continued through the legal process, these consultants will give way. Clients will be directed to ask for help through professional legal agencies or institutions that have collaborated with Pura Koffie. Apart from free legal consultation, what is interesting about Pura Koffie is the concept. Each table is affixed with writings related to the court room, ranging from judges, public prosecutors, to witnesses. ${ }^{4}$

2 Hamzani, A. I. (2019). Legal Culture and the Influence on Law Enforcement In Indonesia. International Journal of Education Humanities and Social Science, 2(5), 79-93.

3 "Kedai Kopi Beri Konsultasi Hukum Gratis bagi Pelanggan", KOMPAS, 11 August 2020, https://www.kompas.tv/article/100916/kedai-kopi-beri-konsultasi-hukumgratis-bagi-pelanggan

4 "Konsultasi Hukum Gratis di Kedai Kopi Alumni Unpas", PAS JABAR, 11 August 2021, https://pasjabar.com/2020/09/21/konsultasi-hukum-gratis-di-kedai-kopialumni-unpas/ 
This concept has actually developed in western countries, especially America. One of them is "Legal Grind: Coffee and Counsel", It all started with a dream and latte. And it's become the best place to get legal advice and attorney referrals in southern California. Since inception in 1996, LegalGrind's Coffee \& Counsel has continually provided clients with access to the best legal advice and representation available, all in an informal, stress-free setting with a low cost for the initial consultation. We meet you where you are most comfortable -an in-person meeting at an attorney's office, a conversation at the local coffee house, or if you are disabled or incapacitated in any way, at your location. That's just part of Attorney and Founder Jeffrey J. Hughes' plan to change the way that you access the law. ${ }^{5}$

By prioritizing the principles of CIVICS (Community, Innovation, Value, Integrity, Collaboration, Service), this cafe is able to provide maximum legal consulting services. Community: Coffeehouses can help bring a sense of community to urban neighborhoods. LegalGrind® fullservice coffee bars and friendly operators allow them to become part of their host communities, setting them apart from the competition. Citizens are focusing on bringing positive change to their communities, which requires interaction with others outside of the home and work. Coffeehouses bring people together in an appealing, relaxing atmosphere to converse and share information, and build a sense of community, all for the cost of a cup of coffee. Innovation: LegalGrind ${ }^{\circledR}$ is dedicated to improving the delivery of legal services to moderate-income people who do not qualify for legal aid yet lack the discretionary income to pay for traditional services. According to Mary K. Ryan, Chair of the ABA's standing committee on the Delivery of Legal Services, "Legal Grind ${ }^{\circledR}$ demonstrates the type of commitment to innovation that the legal profession needs to pursue." Value: In order to create a market for legal services amongst middle- and low-income people, LegalGrind ${ }^{\circledR}$ will continue to make its services setting comfortable and affordable. By driving down the average price through fair competition, by encouraging the client to use only necessary services, and by providing the support that permits clients to appear in court "in pro per" (without an attorney) where advisable, the LegalGrind $®$ has brought quality law within the financial reach of middle-income individuals. According to Founder Jeffrey J. Hughes, "Clients should walk away feeling they got more than what they paid for." Integrity: An ABA Legal Needs Study found that three-fourths of low-income households and two-thirds of middleincome households refuse to seek legal help for their disputes partly because they don't trust attorneys. LegalGrind®'s Coffee \& Counsel ${ }^{\mathrm{SM}}$ blends philanthropic and entrepreneurial interests to help restore the reputation of lawyers. Participating attorneys donate some time in part as

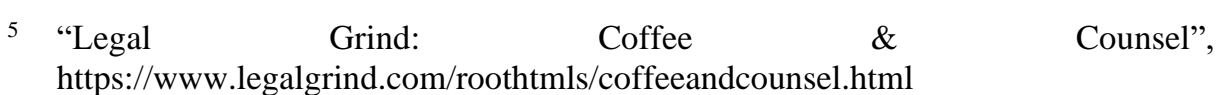


Waspiah Waspiah, et.al.

a gesture of good will, yet they are simultaneously introduced to a new client base and source of referrals. Collaboration: Collaboration between Legal Grind ${ }^{\circledR}$ operators, attorneys and their clients is necessary for those attorneys willing to commit a certain portion of their practice to providing unbundled legal services to pro se clients. LegalGrind ${ }^{\circledR}$ 's attorneys will often delegate their workload to the operator, so the attorney can focus on the more complicated and contested issues that need to be addressed. Likewise, in performing tasks for customers, operators must recognize when a problem goes beyond document preparation, thus necessitating an attorney's attention. Service: LegalGrind ${ }^{\prime}$ 's cutting edge business model would wither on the vine without exemplary customer service. LegalGrind ${ }^{\circledR}$ provides its services in a friendly, one-on-one atmosphere. When contemplating hiring any professional, customers appreciate face-to-face contact; the consumer wants to know his legal matter is personally met with individual care and attention. Additionally, LegalGrind®'s slogan, Justice Served Daily® reminds both attorneys and clients that the legal profession is a service business. ${ }^{6}$

Therefore, this program prioritizes the encouragement of access to justice for the community by combining the concept of legal services and consultation with coffee cafes as a means of consultation that is more convenient and intensive.

\section{LEGAL COUNSELING AND THE CLIENT}

The definition of legal consultants where legal consultants are those who are appointed by the minister of justice to provide legal consultation outside the court as a means of livelihood tree. The mission of establishing a legal consultant based on Law Number 16 of 2011 concerning Legal Aid is contained in Article 6 paragraph (1), namely that legal assistance is held to assist in solving legal problems faced by legal aid recipients. ${ }^{7}$

The rights of legal consultants to clients as stated in Article 9 of Law Number 16 of 2011 concerning Legal Aid, legal consultants have

\footnotetext{
Ibid.

Ardi, Z., Putra, M. R. M., \& Ifdil, I. (2017). Ethics And Legal Issues In Online Counseling Services: Counseling Principles Analysis. Jurnal Psikologi Pendidikan Dan Konseling: Jurnal Kajian Psikologi Pendidikan Dan Bimbingan Konseling, 1522. See also Budijanto, O. W., Mareta, J., Abdillah, J., \& Anggayudha, Z. H. (2021, May). Community Involvement Strategies in Quality Legal Counseling. In $1 s t$ International Conference on Law and Human Rights 2020 (ICLHR 2020) (pp. 103111). Atlantis Press; Kurniawan, N. A. (2020). Peran Paralegal Dalam Perlindungan Serta Pemenuhan Hak Hukum Masyarakat. Jurnal Praksis dan Dedikasi Sosial (JPDS), 3(1), 28-33.
} 
the right to provide legal aid services, legal consultations, legal protection during the provision of legal aid, and other matters relating to the provision of assistance client law. The obligations of legal consultants to clients as stated in Article 10 of Law Number 16 of 2011 concerning Legal Aid, namely legal consultants are required to maintain the confidentiality of the client's data and provide information related to the case that is being experienced by the client concerned.

Meanwhile, clients or recipients of legal aid are not only poor people, but anyone who experiences problems and solves them through the services of a legal consultant is also called a client or recipient of legal aid. Recipients of legal aid in accordance with Article 12 of Law Number 16 of 2011 concerning Legal Aid are entitled to:

a. Obtain legal assistance until the legal problem is resolved and/or the case has permanent legal force, as long as the recipient of the legal aid concerned does not revoke the power of attorney.

b. Obtain legal assistance in accordance with the Legal Aid Standards and/or the Advocate's Code of Ethics; and

c. Obtain information and documents related to the implementation of the provision of legal aid in accordance with the provisions of the legislation.

Article 14 of Law Number 16 of 2011 concerning Legal Aid regulates the obligations of legal aid recipients in order to obtain legal assistance from legal aid providers in the form of conditions. The conditions as stated in Article 14 paragraph (1) of Law Number 16 of 2011 concerning Legal Aid are in accordance with the condition of the client, in this case the client is the party who is the victim of domestic violence. $^{8}$

\section{PARALEGAL AND LEGAL CONSELING: A COFFE AND COUNSEL CLINIC FOR ACCESS TO JUSTICE}

A paralegal is a representative of a community/organization who is given legal knowledge and skills to help the poor and marginalized. Paralegals have developed since 1970, their role is to help small communities who

8 Fattah, I., \& Muthmainnah, M. (2021). Peran Paralegal Mendampingi Korban Kekerasan Perempuan dan Anak di Kota Parepare. Jurnal Pendidikan Kewarganegaraan Undiksha, 9(2), 384-395; 1stri Dharmasatyari, C., Sugiartha, I. N. G., \& Karma, N. M. S. (2021). Peran Pendamping (Paralegal) dalam Memberikan Perlindungan Hukum Bagi Perempuan Korban Kekerasan dalam Rumah Tangga. Jurnal Preferensi Hukum, 2(2), 218-222; Gunawan, Y., \& Hafiz, M. B. A. (2021). Pendidikan Paralegal Bagi Masyarakat Sebagai Wujud Pemenuhan Hak Asasi Manusia Berkelanjutan. Berdikari: Jurnal Inovasi dan Penerapan Ipteks, 9(1), 87-97. 
Waspiah Waspiah, et.al.

need legal assistance. A person who becomes a paralegal does not have to be a legal scholar or receive legal education at a university, but he or she must attend special paralegal education. In this special education, paralegals are given some basic knowledge and some basic skills. The term Paralegal refers to someone who is not an advocate but has knowledge in the field of law, both material law and procedural law with the supervision of lawyers or legal aid organizations that play a role in helping people seeking justice.

Article 1 paragraph (1) of Law No. 16 of 2011 concerning Legal Aid states that legal aid is legal services provided by Legal Aid Providers free of charge to Legal Aid Recipients. Article 9 letter a stated that legal aid providers have the right to recruit advocates, paralegals, lecturers, law faculty students.

The regulation of paralegal function is regulated in Article $16 \mathrm{PP}$ No. 42 of 2013 concerning the terms and procedures for providing legal aid. Article 16 mandates paralegals to run legal aid services on a nonlitigation basis. Article 16 paragraph (2) mandates that there are 9 paralegal functions in providing legal aid services.

Law Number 16 of 2011 concerning Legal Aid has given juridical legitimacy to the existence of Paralegals as part of legal aid providers. The requirements to become a paralegal are specifically regulated by the institution/agency that registers paralegals. In general, the requirements to become a paralegal are:

1. Must attend all series of activities

2. LBH clients and active in the community,

3. Willing to do advocacy work.

4. For networking, focusing on human rights advocacy work

5. Willing to spend time, energy, and thoughts to help the village community (Voluntarian)

6. Fill out the confirmation sheet

Anyone can become a paralegal, for example: community leaders, tribal leaders, religious leaders, youth leaders, students, trade union activists, farmer union activists, teachers, and other community members. To become a Paralegal, a person must at least attend paralegal education, both basic education and further education. A person who has registered as a paralegal must attend all legal training provided by the legal aid agency/institution that oversees the paralegal.

The basic values that must be adhered to by a paralegal, when doing paralegal work are:

1. Honesty, openness, fairness, responsibility, non-violence, and independence.

2. Do not discriminate against a person on the basis of differences in ethnicity, religion, culture and gender

3. Upholding the values of justice, truth and human rights, 
4. Have self-confidence and courage to uphold justice with various risks,

5. Do not abuse their role for personal or group interests.

A person who has become a paralegal must have the following attitudes and personalities:

1. Have honesty.

2. Being chivalrous and virtuous.

3. Uphold the values of justice, truth and human rightsbased on Pancasila and the 1945 Constitution.

4. Fight for the rights of the poor, the blind and the oppressed without discriminating against anyone in any form.

5. Able to maintain self-respect and the good name of Paralegals.

6. Act wisely and do not ignore the interests of the community.

7. Be open and willing to accept criticism that is build.

8. Able to improve themselves and increase the ability in perform its role.

9. Think objectively and be able to do analysis so that you can understand the real problem and find the best possible solution.

10. Creative in utilizing ethical methods and available resources so that they can be used to help the community.

11. Able to collaborate with various professions in an effort to find real problems and efforts to solve them.

12. In assisting cases of a civil nature as far as possible resolve peacefully and respect the rules, customs, culture and values that apply in society.

\section{CONCLUSION}

This paper concludes that paralegals have an important role in accelerating access to justice for people in Indonesia. The combination of service methods and legal consultation through coffee cafes and legal consulting services has become a breakthrough in accelerating access to justice and increasing the rigidity of legal services so far. On the one hand, the client can obtain maximum legal services, on the other hand, the client's psychology is maintained because of the comfortable atmosphere and environment.

\section{REFERENCES}

"Kedai Kopi Beri Konsultasi Hukum Gratis bagi Pelanggan", KOMPAS, 11 August 2020, https://www.kompas.tv/article/100916/kedaikopi-beri-konsultasi-hukum-gratis-bagi-pelanggan 
Waspiah Waspiah, et.al.

"Konsultasi Hukum Gratis di Kedai Kopi Alumni Unpas", PAS JABAR, 11 August 2021, https://pasjabar.com/2020/09/21/konsultasihukum-gratis-di-kedai-kopi-alumni-unpas/

"Legal Grind: Coffee \& Counsel",
https://www.legalgrind.com/roothtmls/coffeeandcounsel.html

Ardi, Z., Putra, M. R. M., \& Ifdil, I. (2017). Ethics And Legal Issues In Online Counseling Services: Counseling Principles Analysis. Jurnal Psikologi Pendidikan Dan Konseling: Jurnal Kajian Psikologi Pendidikan Dan Bimbingan Konseling, 15-22.

Budijanto, O. W., Mareta, J., Abdillah, J., \& Anggayudha, Z. H. (2021, May). Community Involvement Strategies in Quality Legal Counseling. In 1st International Conference on Law and Human Rights 2020 (ICLHR 2020) (pp. 103-111). Atlantis Press.

Fattah, I., \& Muthmainnah, M. (2021). Peran Paralegal Mendampingi Korban Kekerasan Perempuan dan Anak di Kota Parepare. Jurnal Pendidikan Kewarganegaraan Undiksha, 9(2), 384-395.

Gunawan, Y., \& Hafiz, M. B. A. (2021). Pendidikan Paralegal Bagi Masyarakat Sebagai Wujud Pemenuhan Hak Asasi Manusia Berkelanjutan. Berdikari: Jurnal Inovasi dan Penerapan Ipteks, 9(1), 87-97.

Hamzani, A. I. (2019). Legal Culture and the Influence on Law Enforcement In Indonesia. International Journal of Education Humanities and Social Science, 2(5), 79-93.

Herdiana, D., Susanto, S., Iqbal, M., Indriani, I., \& Supriyatna, W. (2021). Pelatihan Penggunaan Aplikasi E-Court Untuk Paralegal Di Lembaga Bantuan Hukum "UNGGUL". Abdi Laksana: Jurnal Pengabdian Kepada Masyarakat, 2(1), 110-115.

Kurniawan, N. A. (2020). Peran Paralegal Dalam Perlindungan Serta Pemenuhan Hak Hukum Masyarakat. Jurnal Praksis dan Dedikasi Sosial (JPDS), 3(1), 28-33.

lstri Dharmasatyari, C., Sugiartha, I. N. G., \& Karma, N. M. S. (2021). Peran Pendamping (Paralegal) dalam Memberikan Perlindungan Hukum Bagi Perempuan Korban Kekerasan dalam Rumah Tangga. Jurnal Preferensi Hukum, 2(2), 218-222.

Noni, N. P. N. S., Sugiantari, A. A. P. W., \& Nistra, I. M. (2021). Efektivitas Peraturan Menteri Hukum dan HAM Nomor 1 Tahun 2018 Tentang Paralegal Dalam Pemberian Bantuan Hukum Di LBH-APIK Bali. Jurnal Analisis Hukum, 4(1), 16-33.

Rahardian, R., Haryanti, R. H., \& Kurnia, N. A. S. (2018). Evaluating The Use of Paralegal Approach in Policy Advocacy. JKAP (Jurnal Kebijakan dan Administrasi Publik), 22(1), 14-19.

Sihombing, E. N. (2019). Eksistensi Paralegal dalam Pemberian Bantuan Hukum bagi Masyarakat Miskin. Jurnal Ilmiah Penegakan Hukum, 6(1), 70-77. 
Waspiah Waspiah, et.al.

Justice consists

in doing no

injury to men;

decency in

giving them no

offense.

Marcus Tullius Cicero 
Waspiah Waspiah, et.al.

\section{Conflicting Interest Statement}

All authors declared that there is no potential conflict of interest on publishing this article.

Funding

None

\section{Publishing Ethical and Originality Statement}

All authors declared that this work is original and has never been published in any form and in any media, nor is it under consideration for publication in any journal, and all sources cited in this work refer to the basic standards of scientific citation.

Cite this article as:

Waspiah, W., Rodiyah, R., Setiawan, A., Cahyani, K. F., Pertiwi, A. R., \& Bimantara, B. (2021). Coffee and Counsel Clinic: Constructing a More Comfortable Place for Legal Aid in the Sub-Urban Community. The Indonesian Journal of International Clinical Legal Education, 3(3), 399410. https://doi.org/10.15294/ijicle.v3i3.48609 